\title{
Policies for Improved Food Security: The Roles of Land Tenure Policies and Land Markets
}

\author{
Stein T. Holden
}

\begin{abstract}
This chapter provides an overview of what we know about farm size distributions, the emerging land markets, the role of tenure systems, tenure reforms and land policies in shaping the distribution of increasingly scarce land resources. The primary focus is on Africa while making some comparisons with Asia. Climate risk and change have serious implications for household vulnerability and food security. While there is a need to absorb further population growth in rural areas, a rapid rise in rural-urban migration is inevitable. Careful land use planning and tenure reforms are needed to smooth the transition towards more intensive land use.
\end{abstract}

\section{Introduction}

Land scarcity is growing in many parts of Africa, and land markets are emerging and becoming more active (Holden et al. 2008). Population growth has also put increasing pressures on customary tenure systems. The sharp increase in demand for land following the hikes in food and energy prices in 2007-2010 revealed weaknesses in land tenure systems and policies (Deininger et al. 2014). The increased investor demand for land created fears that vulnerable groups and smallholders would lose their land rights and become more food insecure (de Schutter 2011; German et al. 2013). This chapter provides an overview of what we know about the emerging land markets in Africa, the role of tenure systems, tenure reforms and land policies in shaping the distribution of increasingly scarce land resources and draws implications for future farm size distributions and livelihood opportunities for the current large and growing rural populations in the continent. Rural-urban migration and international migration are expected to grow rapidly, and management of this flow of people will have to be a central element of more holistic tenure policies. Provision of food at affordable prices, for the growing rural and urban populations facing climate change with more turbulent weather conditions, is an increasing challenge.

\footnotetext{
S. T. Holden ( $\varangle)$

School of Economics and Business, Centre for Land Tenure Studies, Norwegian University of Life Sciences, P. O. Box 5003, 1432 Ås, Norway

e-mail: stein.holden@nmbu.no

(C) The Author(s) 2020

S. Gomez y Paloma et al. (eds.), The Role of Smallholder Farms in Food and Nutrition Security, https://doi.org/10.1007/978-3-030-42148-9_8
} 
There are signs of a more rapid transformation of the agricultural sector in many African countries with high economic growth, infrastructure investments and new technologies. New technologies have also sharply reduced the costs of formalisation of land rights. Land tenure reforms using low-cost methods have been scaled up in a number of countries and appear to have contributed to enhanced tenure security and better functioning land markets. However, the devil is in the detail of land tenure reforms, in terms of specific details, interpretation and implementation. These can have long-term impacts on the distribution of power, land resources, economic performance, welfare and welfare distribution.

Reforms that enhance land rental markets appear important as a tool to facilitate a transformation towards more productive commercial agriculture that is capable of feeding the growing urban populations in Africa. The rapid urbanisation process in some areas is putting high pressure on tenure systems, and good governance is extremely important to minimise conflicts and facilitate smooth transition. The recent political unrest in Ethiopia was also partly triggered by the need to expand the borders of Addis Ababa, met by protests by those losing their land with minimal compensation offered compared to the potential value of the land. Rapid economic transformation and shocks also cause rapid social changes and stress that can ignite social unrest and political conflicts, threatening political stability.

I aim to assess the following research questions: What are the implications of population growth and increasing land scarcity for livelihood opportunities and food security in Africa? Will land markets stimulate land access for the land-poor? Will tenure reforms benefit small farmers or be to their disadvantage?

\section{Population Growth, Farm Size Distribution and Food Security}

According to the High Level Panel of Experts on Food Security and Nutrition (HLPE 2013), there was a general decrease in average farm size in Africa and in China during the period 1930-2000. Using data from 2000 for 81 countries, they find that $73 \%$ of the farms were smaller than 1 ha and $85 \%$ were smaller than 2 ha. In 14 African countries, $80 \%$ of the farms were smaller than 2 ha, and these utilised $25 \%$ of the agricultural land. Masters et al. (2013) indicates that the trends towards smaller holdings have changed in Asia in recent years. Jayne et al. (2014) find that farm sizes are shrinking in land-constrained countries in Africa, such as Ethiopia, Kenya, Malawi, Nigeria, Rwanda and Uganda, but are increasing in some more land-abundant countries, such as Tanzania and Zambia in recent years.

In low-income countries, we may distinguish two main trends in farm size distribution. The first trend, which is affecting the majority of densely populated rural areas, is an increasing pressure on land due to population growth and absorption of more people on the land. This trend is strongest in sub-Saharan Africa (SSA), where it is predicted that the rural population will increase by $60 \%$ from 2015 to 2050 (United 
Nations 2014). This leads to continued fragmentation into smaller farm sizes and is partly driven by the dominant inheritance rules, where land tends to be split among children of the parents.

How far this fragmentation process will go in different environments will depend on what is a minimum farm size for an acceptable rural livelihood, given the combination of farm productivity and alternative sources of income that are available to those living on the farm. What is an acceptable rural livelihood depends on cultural norms, as well as alternative and complementary economic opportunities. A rural livelihood may potentially become a poverty trap ('small is ugly'); if population growth in such areas is stronger than productivity growth, the costs of escaping the locality are too high, and the known alternatives elsewhere are not considered attractive.

Severe shocks to such a poverty-trapped vulnerable locality may cause desperate migration and/or local disaster. Covariate shocks are more serious in isolated areas because they are associated with large endogenous price changes that add to the costs of consumption smoothing. Households that may be net sellers of food under favourable climatic conditions may become net buyers of food in drought or flood years. Poor market integration causes loss-loss price effects for such households, as they have to sell their surpluses in good years at very low prices and buy their deficits at very high prices in years with covariate weather shocks. If they keep livestock as a means of protecting themselves against such shocks, livestock prices also tend to fluctuate in their disfavour, as they may have to sell livestock at low prices in order to buy food at a high price in shock years. When they have recovered after a shock and want to rebuild their livestock, livestock prices are again likely to be high (Holden and Shiferaw 2004).

The trend towards fragmentation into smaller farms is also associated with an increasing share of rural farm households becoming deficit producers of staple food. Climate change may contribute to larger risks and uncertainty in agricultural production and enhance the vulnerability of smallholder farmers, who may become even more food insecure. Investments in infrastructure and market integration may contribute to reduce price fluctuations due to covariate risk, and technological improvements may contribute to adaptation and reduction in production risks. However, provision of food to the rapidly growing urban populations will require large increases in agricultural production and in marketed surpluses.

There are likely to be diminishing returns to labour as labour/land ratios are increasing when farm sizes get very small. An inverse relationship (IR) between farm size and land productivity has frequently been observed within smallholder agriculture, and this relationship appears to be not only due to land quality differences and measurement error (Carletto et al. 2013). Labour and land market imperfections are at the heart of the IR. Moral hazard causes hired labour not to be a perfect substitute for family labour. In combination with seasonality and search costs in the labour market, there is a tendency that higher labour/land ratios on farms are associated with more intensive labour use per unit land, and this may also be associated with lower shadow wages and thus higher output per unit land (land use intensification). However, this may also be affected by access to other productivity-enhancing inputs than labour. If the most land-poor but labour-rich have limited access to input markets 
and improved technologies, or need access to credit in order to afford to buy inputs, they may be too poor to invest and to be efficient (Holden and Binswanger 1998). There is also a risk that their labour-intensive practices contribute more to soil mining or land degradation if they do not replace lost nutrients or conserve the land properly (Shiferaw and Holden 1998).

With continued rural population growth and expansion of super-small farms, pushrather than demand-driven outmigration is likely to increase over time, and employment creation for such migrants will become critical for economic development and social stability. The stochastic nature of shocks is also likely to cause stochastic migration flows, unless there is institutional and governance capacity to cushion the effects of such shocks.

A change in inheritance rules may help to prevent fragmentation into smaller farms, e.g. by requiring that only one of the children in the family can inherit the land to ensure that the farm size remains intact. Setting of minimum farm sizes for legal registration may be another way to attempt to stem this trend, but whether and how it will work is an empirical issue. Facilitation of consolidation into larger farm sizes is another option. The success of such policies will depend on the incentives and the degree of compliance. There are few studies that have assessed the costs and benefits of such land fragmentation. A study by Ali and Deininger (2015) in Rwanda-the most densely populated country in Africa, where the average farm size is 0.72 ha (on average split into four parcels) — shows that this is not sufficient to meet household food needs. The national land policy prohibits splitting of farms into units smaller than 1 ha and advocates land consolidation and mobilisation of land for investors. The study finds, however, a strong IR when controlling for householdspecific shadow wages and a strong ability of small farms to absorb labour in a productive way, while the IR disappears when market wages are used to calculate area-based profits. A policy that generates employment and higher wages outside agriculture is likely to be better than a forced consolidation policy that may do more harm than good in such a context.

\section{Expansion of Medium-Sized Farms}

The other trend of significant importance is the expansion of medium-sized farms observed in, for example, Ghana, Kenya, Malawi and Zambia (Anseeuw et al. 2016; Sitko and Jayne 2014; Jayne et al. 2016). This trend is associated with urban expansion and land acquisition by African elites. The trend is strong enough to threaten small farm development and reduce land access for land-poor smallholders. This expansion may have been boosted by rising energy and food prices and facilitated by weak land governance and tenure systems. It is uncertain whether customary tenure reforms will hinder or further boost this development through privatisation of land rights and land market development. While some earlier studies in East Africa did not reveal that land sales contributed to a more skewed land distribution (Holden 
et al. 2008), more recent studies point in the direction of a more skewed land distribution because of the expansion of large and medium-sized farms in combination with further subdivision of small farms (Jayne et al. 2016).

Whether this increase in medium-sized farms will lead to increased land productivity and improved food security overall depends on a number of factors. If those taking over or buying such farms are doing it to establish productive agriculture and they possess the necessary skills, social networks and other forms of capital, this may enhance efficiency. If, on the other hand, they do it to establish a rural resort for retirement and as a tax shelter, the outcome may be reduced land productivity. Anseeuw et al. (2016) found that a large share of the owners of medium-sized farms in Malawi were urban dwellers and part-time farmers. Sitko and Jayne (2014) found a similar situation in Zambia. Their studies indicate that the rural growth linkages become weaker with this kind of change in ownership structure, as more of the income remains in urban areas.

There is a shortage of good studies carefully comparing productivity on mediumsized versus small farms. In general, there are few economies of scale in agriculture in low-income countries (Binswanger and Rosenzweig 1986). Anseeuw et al. (2016) find that the share of unutilised land increases with farm size in Malawi. While policies in Malawi favoured estate agriculture up until the early 1990s, including through prohibition of smallholder tobacco production, the removal of these policies caused a rapid expansion of smallholder tobacco production while many tobacco estates put more land under fallow. The relatively low utilisation of estate land in the country contributed to a 'market-assisted land redistribution' project, providing 15,000 landless or near landless households with farmland, and this project appears to have had positive impacts (Simtowe et al. 2013). On the other hand, Ali et al. (2015) find that medium-sized farms have higher land productivity than small farms in Ethiopia. Farms in the range of 10-20 ha had the highest land productivity for most crops. However, the data were not good enough to control for land quality or labour use intensity, which potentially could be correlated with farm size. They found that commercial farms had on average one permanent job per 20 ha, with some additional temporary jobs, and this is far below smallholder agriculture in the country where a family farm may only be 1 ha and thus possibly absorbing 20 times more labour per unit land. With about 80 million of the 100 million population in Ethiopia still engaged primarily in smallholder agriculture, and with population growth of about 2.6 million per year, providing alternative employment to transform smallholder agriculture to commercial agriculture is not a trivial challenge.

A conversion from small farms to larger (medium-sized) farms will require a livelihood solution for those populations that have to give up their small farms in order to provide the space for larger farms. If those populations can be provided with attractive better livelihoods in urban areas and the non-farm sector, the transformation of small farms into medium and large farms may be socially optimal and be consistent with what has happened in many western countries. It could lead to a drastic reduction in rural poverty. However, it would have to be driven by very strong economic growth outside the agricultural sector. It may be too optimistic to hope for this in all developing countries with large rural populations concentrated on small farms, 
although economic growth has increased in many African countries over the last two decades. On the other hand, it may be less challenging to establish medium and large farms in areas with low population density, although this will also depend on traditional land rights and the existence of customary tenure systems.

In China, rural wages have started to increase in recent years, and this has also triggered a move towards larger farm sizes there. However, it took many years of strong economic growth, even in China with its population control policy, to eliminate the surplus labour in rural areas to the extent that rural wages have started to rise due to labour scarcity in these areas. It may take even longer to see such an effect in countries with similar economic growth and larger rural population growth.

\section{Increasing Landlessness and Migration}

We are still haunted by Malthusian theory. There is a danger that poor smallholders become too poor to invest and unable to maintain the productivity of the land on which they subsist (Holden and Binswanger 1998; Shiferaw and Holden 1998), unless systematic actions are taken to promote sustainable intensification of smallholder agriculture. While there are many examples of success stories (Boserupian pathways), and evidence that promotion of tenure security enhances incentives to conserve land, secure tenure rights is only a necessary-not a sufficient-condition to ensure sustainable land use on smallholder farms (Holden et al. 1998, 2009). Comprehensive tailor-made policies are needed to handle diverse and densely populated rural livelihood systems. Whether diversification, intensification and growth can be facilitated within the economy, or whether outmigration or strict family planning to curb population growth is needed, is an empirical issue. China succeeded with the household responsibility system, population control and export-oriented industrialisation policies, and rural wages and farm sizes have started to rise in recent years. For more densely populated and land-constrained African countries where economic growth has picked up, rural population growth is still high and continues to concentrate on small farms. This represents a massive push towards the minimum bearable farm size, and a rapidly growing number of young people are pushed over the cliff into landlessness. Growing national and international youth migration is an inevitable outcome and a huge challenge.

In Asia, landlessness has in the past been closely associated with poverty, due to the importance of land as a source of income in rural areas (Pakistan: Anwar et al. 2004; India: Meenakshi and Ray 2002; Philippines: Balisacan 1993). However, landlessness may also be an indicator of growing diversification in rural economies, and the finding of poor correlation in some countries between poverty and landlessness shows that landlessness can also be a sign of better opportunities (Lanjouw 2007). Ravallion and van de Walle (2008) found that recent increases in landlessness in Vietnam are not associated with higher levels of poverty. The differentiation in rural areas of Vietnam after strong economic growth appears to have reached a stage where landlessness is decoupled from poverty. 
Landlessness is growing rapidly in densely populated poor agrarian economies, and in such economies, the landless may be among the poorest of the poor. In undifferentiated land-constrained rainfed agriculture, it may even be very hard to survive if landless as there may be very few jobs available that provide a livelihood throughout the year, unless one has some specialised skills or education. Outmigration may thus be the best and only option for the landless in such areas that have passed a certain threshold level of population density (Bezu and Holden 2014). While this may occur quite suddenly in some egalitarian societies with equitable land distribution, it may occur more gradually in areas with more variation in farm sizes. Climatic and other forms of covariate shocks may also trigger massive migration within short periods of time unless organised actions are taken to buffer such shocks. Migrants have to leave immobile assets, including their land, behind. Without compensation for such immobile assets and with inability to return, they are likely to be extremely poor and also to be very vulnerable wherever they go. Whether it is better that these asset values stay behind with the remaining rural population, or go with the migrants as capital to help them start a new livelihood, is also an empirical issue. Extreme rural poverty, contrasting with better-off urban livelihoods and adequate job opportunities where migrants go, may point in direction of retaining the asset values in the rural areas of origin. This implies that, for example, the child in the family that remains behind and takes over the family farm does not need to compensate their siblings who have to migrate and do not inherit any of the immobile assets.

On the other hand, with a functioning rural land sales market, the whole family may decide to sell their immobile assets. While this may help migrants to get start-up capital, there is also a risk that it can lead to distress land sales, increasing landlessness and accumulation of land in the hands of the wealthy (Holden et al. 2008; Jayne et al. 2016). In countries with powerful urban elites who influence land governance through law formation or law violations, there is a higher risk that land tenure reforms and land markets contribute to more inegalitarian land distribution, in a way that also makes poverty worse.

In many developing countries, the traditional way of preventing landlessness in rural areas has been through inheritance, sharing the land among the children. In some countries, there has even been a constitutional right for rural residents to access land for free as they become old enough to establish their own family (e.g. Ethiopia). Customary tenure systems have also had such rules for land allocation to clan members. Such allocation mechanisms function only up the point where land scarcity creates a gap between demand and supply of land. In Ethiopia, they have recently started to allocate rehabilitated communal lands to groups of landless youth. Providing them with temporary licences to extract mineral resources is another approach to help them generate starting capital for another business (Holden and Tilahun 2018). 


\section{Land Market Development}

Land scarcity and the existence of a price for land, where there is a willing seller and a willing buyer, are the fundamental requirements for a land sales transaction and a land market to occur. Such land sales transactions can lead to more productive land use, if the buyer primarily aims to use the land for productive purposes. However, if they were able to buy it under distress conditions for the seller, and thus obtained it at a very favourable price, the desperate seller may under the circumstances have been forced to sell the land at a price below their own long-term value of the land. It is thus not necessarily the case that land sales transactions transfer land from less productive to more productive farmers. But under normal conditions, where the purchase is for productive purposes, buyers of land may also turn out to be more productive users of the land than those who sold the land. However, output price fluctuations, such as the high energy and food prices during the period 2007-2011, also triggered high demand for land. The later unexpected fall in energy prices affected land use efficiency on land obtained by investors who typically took on large areas of land under long-term lease arrangements. Planting of energy crops is no longer profitable. Demand for land for food production by smallholder farmers is much less elastic.

Whether the development of a land sales market leads to a concentration of land in the hands of the few, and growing landlessness, is also an empirical question. Unequal land distributions are however more often the outcome of political processes, rather than redistributions through the land sales market. Some studies in Africa indicate that land purchases are made by land-poor but capital-rich persons and do not necessarily lead to more inegalitarian land distribution (Deininger and Mpuga 2008). This also implies that most owners of small farms are willing to sell their farms, and it may not be realistic in the foreseeable future to see a transition from small farms to medium-sized farms through an active land sales market in most African and many Asian countries. A recent study in Ethiopia (Holden and Bezu 2016) revealed a strong resistance against opening the land sales market and very high and increasing willingness to accept (WTA) prices for land.

One trigger towards the development of larger farm sizes appears to be rural wages. When the cost of labour in agriculture increases, we start to get a substitution into more capital-based production, as mechanisation becomes both labour- and cost-saving. There are limited or no economies of scale in most forms of tropical agriculture (Binswanger and Rosenzweig 1986; Binswanger et al. 1995), and hired labour is not a perfect substitute for family labour, thus giving family-based production a comparative advantage. Economies of scale exist in processing and marketing, and some forms of land development such as investment in irrigation, drainage and building of roads, and that is where large private companies can play an important role (Byerlee et al. 2015). However, even in land-abundant frontier areas, the most successful land development projects have involved subdivision of land for family farming (Byerlee et al. 2015).

In relation to the commercialisation of agriculture and development of the supply chain for agricultural products, such as the expansion of supermarkets, contract 
farming by smallholder producers has in many cases been quite successful. This is an area with a lot of scope for further development, and it could be an avenue to improving food security in a more urbanised world. In Asia, with economic development, a Westernisation of diets and a diversification away from strongly cereal-based diets towards much more varied diets can be observed, and obesity is taking over as the biggest nutrition-related problem (Pingali 2007; Popkin et al. 2012). The development of vertically integrated supply chains is part of this transformation, putting more pressure on the smallholder sector to commercialise, diversify and specialise production. There are more scale economies in some of these specialisations, such as poultry, and this can lead to larger farm sizes (Pingali 2007). More stringent quality standards can also push in the same direction, but this is queried and smallholders are found to supply a large share of the products in such supply chains (Reardon et al. 2009). Diversification of demand by wealthier consumers is also a key to high-value production and on-farm processing of such products. Farmers' markets in urban areas, supplying high-quality farm products, are also a way of raising returns on land and labour and intensifying production. This is a trend in developed countries, and it is likely to also expand in developing countries with the growth of a wealthy middle class.

Secure and well-defined property rights, and well-functioning land markets, are essential to create the incentives for investment in new types of production and obtain more optimally sized production units. While Africa is lagging behind Asia, it is likely to follow a similar evolutionary pathway of diversification and intensification in smallholder agriculture, as urbanisation expands and creates new market opportunities.

Land rental markets have been shown to be pro-poor in many contexts (Holden et al. 2008). Landless or near landless people may access land through renting if they have the necessary complementary resources to utilise the land efficiently. The land rental market can also transfer land from landlords who are poor in non-land resources, to tenants who are rich in non-land resources relative to land resources. Reverse tenancy systems, with poor landlords and relatively wealthier tenants, are dominant in Ethiopia, Eritrea, Madagascar and Tunisia. There has also been a general finding that land rental markets transfer land from less efficient to more efficient producers (Holden et al. 2008, 2013).

In areas where sharecropping is dominant and Marshallian inefficiency prevalent, the efficiency-enhancing effect of land renting is less clear. Otsuka (2007) associates Marshallian inefficiency with land-to-the-tiller reforms that have enhanced tenure insecurity of landowners in several Asian countries. Poor landlords have also been found to have weak bargaining power, and therefore to be less able to choose efficient tenants or enhance their production efficiency, in the reverse tenancy system in Ethiopia (Holden and Bezabih 2008; Ghebru and Holden 2015). Land rental contracts among kin partners have sometimes been associated with higher land use efficiency and in other cases with lower land use efficiency (Sadoulet et al. 1997; Kassie and Holden 2007; Ghebru and Holden 2015).

One may ask what the added value of land rental markets is in rural areas. The basic neoclassical farm household model (Singh et al. 1986) contained no land market 
and yielded no inefficiencies. It is when land is scarce and there are imperfections in non-land markets that re-allocation of resources through the land market can give efficiency gains, by reducing overall transaction costs and enhancing resource use efficiency.

How much agricultural land is reallocated through land rental markets varies substantially across countries. Land markets are likely to be non-existent or very thin in land-abundant countries. A skewed distribution of land relative to non-land resources, low elasticity of substitution among factors of production, and low transaction costs in land relative to non-land factor markets, will increase returns to participation in the land rental market to achieve balanced resource portfolios for production. An active land rental market is also likely to reduce incentives to sell land. It reduces the cost of ownership and enhances the flexibility, as management can be passed on to tenants while retaining land values that may be expected to increase over time with increasing land scarcity and economic development. It also reduces the need for capital in relation to accessing land. The rental market's advantage of reducing the need for credit for buying land may be more important than the usefulness of land as collateral in developing countries where the land sales market does not work well enough to favour the use of land as collateral. De Soto (2000) emphasised the need to formalise property rights in order to 'make dead capital alive', through linking the credit and land market by collateralising land. In developing agrarian economies, it is rather land rental markets that can reduce capital needs and enhance land use efficiency and growth in rural areas. The financial crisis also revealed that having too strong links between the credit and capital markets, through too much borrowing with security in immobile assets, can become the Achilles heel in the economy and contribute to economic instability. Rental markets for immobile assets can, on the other hand, help to create stability and reduce the need for distress sales of such assets.

Airbnb and other forms of short-term rentals are utilising modern information technologies (Internet) to dramatically reduce the transaction costs and information asymmetries in these markets. Transaction costs are still very high in land rental markets in developing countries, but there is scope for reducing these transaction costs and information asymmetries through better registries and information-sharing mechanisms that enhance transparency and accountability in tenure arrangements. This can reduce search, monitoring and enforcement costs for agents and government administrations.

\section{Land Tenure Reforms, Tenure Security and Food Security}

While classical land titling has given very limited benefits, or benefits very skewed in favour of the wealthy and well connected in many developing countries (Jacoby and Minten 2007; Benjaminsen et al. 2009), low-cost reforms to enhance tenure 
security in Ethiopia and Rwanda appear to have had significant positive effects, in terms of enhanced investments in soil conservation (both countries) and tree planting (Ethiopia), enhanced land productivity (Ethiopia) and land rental market activity (Ethiopia) (Deininger et al. 2008, 2011; Holden et al. 2009, 2011; Ali et al. 2014). In Ethiopia, there is also evidence of improved food security and child nutrition, particularly for female-headed households (Holden and Ghebru 2013; Ghebru and Holden 2013), while in Rwanda, land access for legally married women has improved and tenure security and land investments have increased for female-headed households (Ali et al. 2014). This is also likely to have had positive effects on food security in the case of Rwanda, although this has not been investigated by the researchers.

Maxwell and Wiebe (1999) and Holden and Ghebru (2016) have reviewed the literature relating land tenure and land tenure reforms to food security in developing countries. They demonstrate the complexity of such links, and that the literature on tenure issues and food security has largely involved separate fields of inquiry. Lawry et al. (2017) made a systematic review of studies of the impacts of land tenure reforms on investment and agricultural productivity; after reviewing 27,000 studies, they ended up with only 20 holding high-quality impact assessment standards. Ten of these were in Africa, five in Ethiopia. The external validity of these few highquality studies may be questioned, given the diversity of tenure systems and their complex dynamics. There is clearly a need for more high-quality studies. But for policy purposes, we still need to draw on lower-quality studies. The urgency of issues limits how much we can rely on experimental designs that the 'randomistas' have argued to be the way forward in promoting economic development in developing countries. Such experiments are not a panacea solution in all-important developing country contexts where interventions are needed. Tenure systems are complex, and other forms of contextual and spatial heterogeneity are also important. We therefore need to pay careful attention to the underlying causal mechanisms, and we need structural models to capture more of the complexity, longer-run impacts and chain reactions related to tenure systems and tenure reforms (Deaton 2010).

There is clearly a need for more studies of the relationship between land tenure and food security in different contexts. The sharp increases in demand for land, related to the energy and food price boom in 2007-2010, revealed that investors obtained more land where tenure systems were poorly developed and population densities were low (Deininger and Byerlee 2012). However, there are also people with customary land rights in such areas, although their rights may not have been recognised by statutory law. Within the complex area of customary tenure, more attention needs to be paid to preventing the marginalisation of population groups with limited political influence, as their food and livelihood security can otherwise be threatened. While there is an urgent need to strengthen land governance in many countries, there is also a high risk that such reforms lead to elite capture given the trend in land distribution, converting customary land to state land for allocation to investors, as observed in a number of African countries (Jayne et al. 2016).

Important factors for whether customary land and smallholder farmers are protected from land acquisitions by investors are: (a) the extent to which customary land and the land rights of holders of customary land are recognised in statutory law; 
(b) whether it is possible to convert customary land to state land and put it under long-term lease to investors; (c) whether customary land that has been converted and transferred to investors reverts to customary land at the end of the lease; (d) whether traditional leaders have the freedom to transfer customary land to investors and (e) whether the state can expropriate customary land for allocation to investors, possibly without any need to compensate those who have lost the land.

Alden Wily (2015) shows how a tenure reform in Côte d'Ivoire threatens to eliminate the land rights of people who have not been able to obtain a land title by a specific date. Other countries have attempted to integrate customary tenure systems into statutory law, e.g. by establishing customary tenure titles or certificates. Malawi is one of the countries now attempting this with its new Customary Land Bill, which was passed by Parliament in 2016. Other countries attempting formalisation of customary land rights in this way include Tanzania, Uganda and Zambia. Implementation has been slow in Uganda, while there is some anecdotal evidence of positive effects on tenure security and reduction of disputes in Zambia.

The transition from common property to individual land rights has been seen as a necessary part of the evolution of land rights with growing land scarcity, and there has been a tendency to associate customary tenure with common property. However, individual and household use rights to land can be quite strong in customary systems, although sales rights are often restricted. In studying land use in northern Zambia in low population density areas with long fallows and shifting cultivation in the 1980s, I was surprised myself that even the long fallow woodland areas had borders and belonged to individual households.

Alienation of the less influential also happens in customary systems, and women are particularly exposed in male-dominated customary systems (Peters 2004). Chiefs are usually in a dominant position in such systems, and lack of transparency and accountability has prompted demands for customary tenure reforms and establishment of more transparent and accountable land administrations and land conflict resolution systems. However, this could also be seen as a power struggle between a rural elite (traditional leaders) and an urban elite advocating for land tenure reform and being in a position to take advantage of such a reform. The extent to which the old system or the reform process will better protect the interests of the poor and vulnerable is an empirical issue. In this context, international organisations have an important role in safeguarding the interests of the poor, as well as in supporting reforms that contribute to economic and social development. Good systems for monitoring and impact assessment are essential and require specialised expertise that goes beyond the capacity of each country.

Ensuring food security and tenure security for rapidly growing urban populations is among the most demanding tasks ahead. Urban expansion is inevitable, and it may take place on high-potential agricultural land, leading to irreversible land losses for food production. Better long-term land use planning is crucial, to optimise the use of scarce land resources and to minimise production and transportation costs and greenhouse gas emissions. Good governance, with an emphasis on forward-looking legal and administrative systems, may easily be hijacked by short-term political interests and lead to conflicts that threaten social stability and welfare. 'Random walk' 
development of urban areas may have unforeseen future costs. This may be the case particularly in developing countries facing rapid population growth and urbanisation. Urban planning emphasising vertical rather than horizontal expansion can reduce the pressure on surrounding land areas. Providing young migrants with adequate housing, other social services and jobs is essential for inclusive development. Lowcost rental housing and labour-intensive construction businesses can help with the transition to urban environments for many young people. The Ethiopian youth group model is an interesting approach that may also be suitable in other countries and may work in both rural and urban settings (Holden and Tilahun 2017). It mobilises and organises youth, in rural as well as urban areas, in ways that enhance environmental conservation, resource utilisation, entrepreneurship, employment and infrastructure development.

\section{Conclusions}

Population growth, land degradation, climate change, urban expansion and changing diets are contributing to increasing land scarcity and strong demand for land use intensification to meet future food demands. Uncertainties in terms of timing and severity of agroclimatic and other shocks, including social and political instability, are threatening vulnerable developing economies and their systems of governance.

There is a need for a rapid transformation from rural to urban livelihoods for many in developing countries, while still facilitating absorption of more people on small farms in rural areas in the years to come. This is especially the case in Africa, where there are still large rural populations continuing to grow at a high rate. This will require formidable land use intensification through push and pull mechanisms. Tenure security, well-defined property rights and well-functioning property markets are essential for this transformation, in order to stimulate investment in land, diversification and intensification of production, provision of employment opportunities, affordable housing and other social services in rapidly growing urban areas.

Short-term as well as longer-term land rental and housing markets are essential to reduce the costs of transformation, to buffer shocks and facilitate social mobility. Good and competent governance, that facilitates the transformation through legal provision, and transparent and accountable land administration, will be crucial. National governance systems will need support from international organisations to build their competence and exchange ideas and experience, do careful research and develop better evidence-based policies.

New technologies for land registration, mapping, information dissemination and matching of suppliers and demanders in property markets have great potential, but there is also a high risk of misuse of such information by political elites and rent seekers. This is particularly the case in urban and peri-urban land markets, where property values are increasing very fast and there can be huge rents up for capture through legal as well as illegal processes. Small farms on the fringe of urban areas may see their land being expropriated while receiving minimal, if any, compensation. 
The assignment of rights and the functioning of property markets and government regulation, including property taxation, in these urban and peri-urban areas will be immensely important to the future degree of inequity in wealth.

Small and even smaller farms will persist in rural areas in densely populated developing countries with high population growth. There is a high risk that rural poverty traps may grow in space and severity and trigger destitute migration in waves of growing scale. The migration flow from Africa and the Middle East into Europe over the last couple of years is only the beginning. Investment in smallholder agriculture and political stability in Africa could be one of the best ways to reduce such uncontrolled migration.

\section{References}

Alden Wily, L. (2015, March). Time to rethink? A critique of rural land law in Côte d'Ivoire. FERN Office UK and Brussels. www.fern.org.

Ali, D. A., \& Deininger, K. (2015). Is there a farm size-productivity relationship in African agriculture? Evidence from Rwanda. Land Economics, 91(2), 317-343.

Ali, D. A., Deininger, K., \& Goldstein, M. (2014). Environmental and gender impacts of land tenure regularization in Africa: Pilot evidence from Rwanda. Journal of Development Economics, 110, 262-275.

Ali, D. A., Deininger, K., \& Harris, C. A. P. (2015). Using national statistics to increase transparency of large land acquisition: evidence from Ethiopia. World Bank policy Research Working Paper (p 7342).

Anseeuw, W., Jayne, T., Kachule, R., \& Kotsopoulos, J. (2016). The quiet rise of medium-scale farms in Malawi. Land, 5(3), 19.

Anwar, T., Qureshi, S. K., Ali, H., \& Ahmad, M. (2004). Landlessness and rural poverty in Pakistan [with comments]. The Pakistan Development Review, 855-874.

Balisacan, A. M. (1993). Agricultural growth, landlessness, off-farm employment, and rural poverty in the Philippines. Economic Development and Cultural Change, 41(3), 533-562.

Benjaminsen, T. A., Holden, S., Lund, C., \& Sjaastad, E. (2009). Formalisation of land rights: Some empirical evidence from Mali, Niger and South Africa. Land Use Policy, 26(1), 28-35.

Bezu, S., \& Holden, S. (2014). Are rural youth in Ethiopia abandoning agriculture? World Development, 64, 259-272.

Binswanger, H. P., Deininger, K., \& Feder, G. (1995). Power, distortions, revolt and reform in agricultural land relations. Handbook of Development Economics, 3, 2659-2772.

Binswanger, H. P., \& Rosenzweig, M. R. (1986). Behavioural and material determinants of production relations in agriculture. The Journal of Development Studies, 22(3), 503-539.

Byerlee, D., Masters, W. A., \& Robinson, D. (2015). From land grab to land development: The past and potential of private investment in frontier agriculture. Paper presented at the World Bank Land and Poverty conference, March 23-27, 2015, Washington, DC.

Carletto, C., Savastano, S., \& Zezza, A. (2013). Fact or artifact: the impact of measurement errors on the farm size-productivity relationship. Journal of Development Economics, 103, 254-261.

de Schutter, O. (2011). How not to think of land-grabbing: Three critiques of large-scale investments in farmland. The Journal of Peasant Studies, 38(2), 249-279.

de Soto, H. (2000). The mystery of capital: Why capitalism triumphs in the West and fails everywhere else. Basic books.

Deaton, A. (2010). Instruments, randomization, and learning about development. Journal of Economic Literature, 48(2), 424-455. 
Deininger, K., Ali, D. A., \& Alemu, T. (2011). Impacts of land certification on tenure security, investment, and land market participation: evidence from Ethiopia. Land Economics, 87(2), 312334.

Deininger, K., Ali, D. A., Holden, S., \& Zevenbergen, J. (2008). Rural land certification in Ethiopia: Process, initial impact, and implications for other African countries. World Development, 36(10), $1786-1812$.

Deininger, K., \& Byerlee, D. (2012). The rise of large farms in land abundant countries: Do they have a future? World Development, 40(4), 701-714.

Deininger, K., Hilhorst, T., \& Songwe, V. (2014). Identifying and addressing land governance constraints to support intensification and land market operation: Evidence from 10 African countries. Food Policy, 48, 76-87.

Deininger, K., \& Mpuga, P. (2008). Land markets in Uganda: What is their impact and who benefits? In S. T. Holden, K. Otsuka, \& F. M. Place (Eds.), The emergence of land markets in Africa: Impacts on poverty, equity, and efficiency (pp. 131-155). Washington DC: RFF Press/Routledge.

German, L., Schoneveld, G., \& Mwangi, E. (2013). Contemporary processes of large-scale land acquisition in Sub-Saharan Africa: Legal deficiency or elite capture of the rule of law? World Development, 48, 1-18.

Ghebru, H., \& Holden, S. T. (2013). Links between tenure security and food security: Evidence from Ethiopia. CLTS Working Paper No. 2/2013. Centre for Land Tenure Studies, Norwegian University of Life Sciences, Ås, Norway.

Ghebru, H. H., \& Holden, S. T. (2015). Reverse-share-tenancy and agricultural efficiency: Farmlevel evidence from Ethiopia. Journal of African Economies, 24(1), 148-171.

HLPE. (2013). Investing in smallholder agriculture for food security. A Report by the High Level Panel of Experts on Food Security and Nutrition (Vol. 6). Rome: FAO.

Holden, S. T., Bezabih, M. (2008). Gender and land productivity on rented land in Ethiopia. In: S. T. Holden, K. Otsuka, F. Place (Eds.), The emergence of land markets in Africa: Assessing the impacts on poverty, equity and efficiency (pp. 179-98).

Holden, S. T., \& Bezu, S. (2016). Preferences for land sales legalization and land values in Ethiopia. Land Use Policy, 52, 410-421.

Holden, S. T., \& Binswanger, H. P. (1998). Small farmer decision-making, market imperfections, and natural resource management in developing countries. In: Agriculture and the environment: Perspectives on sustainable rural development (pp. 50-71). Washington, DC: The World Bank.

Holden, S. T., Deininger, K., \& Ghebru, H. (2009). Impacts of low-cost land certification on investment and productivity. American Journal of Agricultural Economics, 91(2), 359-373.

Holden, S. T., Deininger, K., \& Ghebru, H. (2011). Tenure insecurity, gender, low-cost land certification and land rental market participation. Journal of Development Studies, 47(1), 31-47.

Holden, S. T., \& Ghebru, H. (2013). Welfare impacts of land certification in Tigray, Ethiopia. In S. T. Holden, K. Otsuka, \& K. Deininger (Eds.), Land tenure reform in Asia and Africa: Assessing impacts on poverty and natural resource management (pp. 137-161). London: Palgrave Macmillan.

Holden, S. T., \& Ghebru, H. (2016). Land tenure reforms, tenure security and food security in poor agrarian economies: Causal linkages and research gaps. Global Food Security, 10, 21-28.

Holden, S. T., Otsuka, K., \& Deininger, K. (Eds.). (2013). Land tenure reform in Asia and Africa: Assessing impacts on poverty and natural resource management. London: Palgrave Macmillan.

Holden, S. T., Otsuka, K., \& Place, F. M. (Eds.). (2008). The emergence of land markets in Africa: impacts on poverty, equity, and efficiency. Washington, DC: RFF Press/Routledge.

Holden, S., \& Shiferaw, B. (2004). Land degradation, drought and food security in a less-favoured area in the Ethiopian highlands: A bio-economic model with market imperfections. Agricultural Economics, 30(1), 31-49.

Holden, S. T., Shiferaw, B., \& Wik, M. (1998). Poverty, market imperfections, and time preferences: Of relevance for environmental policy? Environment and Development Economics, 3, 105-130.

Holden, S. T., \& Tilahun, M. (2018). The importance of Ostrom's design principles: Youth group performance in Northern Ethiopia. World Development, 104, 10-30. 
Jacoby, H. G., \& Minten, B. (2007). Is land titling in Sub-Saharan Africa cost-effective? Evidence from Madagascar. The World Bank Economic Review, 21(3), 461-485.

Jayne, T. S., Chamberlin, J., \& Headey, D. D. (2014). Land pressures, the evolution of farming systems, and development strategies in Africa: A synthesis. Food Policy, 48, 1-17.

Jayne, T. S., Chamberlin, J., Traub, L., Sitko, N., Muyanga, M., Yeboah, F. K., et al. (2016). Africa's changing farm size distribution patterns: the rise of medium-scale farms. Agricultural Economics, 47(S1), 197-214.

Kassie, M., \& Holden, S. T. (2007). Sharecropping efficiency in Ethiopia: Threats of eviction and kinship. Agricultural Economics, 37(2-3), 179-188.

Lanjouw, P. (2007). Does the rural nonfarm economy contribute to poverty reduction. In S. Haggblade, P. B. Hazell, \& T. Reardon (Eds.), Transforming the rural nonfarm economy: Opportunities and threats in the developing world (pp. 55-79). Washington, DC: International Food Policy Research Institute.

Lawry, S., Samii, C., Hall, R., Leopold, A., Hornby, D., \& Mtero, F. (2017). The impact of land property rights interventions on investment and agricultural productivity in developing countries: A systematic review. Journal of Development Effectiveness, 9(1), 61-81.

Masters, W. A., Djurfeldt, A. A., De Haan, C., Hazell, P., Jayne, T., \& Jirström, M. (2013). Urbanization and farm size in Asia and Africa: Implications for food security and agricultural research. Global Food Security, 2(3), 156-165.

Maxwell, D., \& Wiebe, K. (1999). Land tenure and food security: Exploring dynamic linkages. Development and Change, 30(4), 825-849.

Meenakshi, J. V., \& Ray, R. (2002). Impact of household size and family composition on poverty in rural India. Journal of Policy Modeling, 24(6), 539-559.

Otsuka, K. (2007). Efficiency and equity effects of land markets. Handbook of Agricultural Economics, 3, 2671-2703.

Peters, P. E. (2004). Inequality and social conflict over land in Africa. Journal of Agrarian Change, 4(3), 269-314.

Pingali, P. (2007). Westernization of Asian diets and the transformation of food systems: Implications for research and policy. Food Policy, 32(3), 281-298.

Popkin, B. M., Adair, L. S., \& Ng, S. W. (2012). Global nutrition transition and the pandemic of obesity in developing countries. Nutrition Reviews, 70(1), 3-21.

Ravallion, M., \& Van de Walle, D. (2008). Does rising landlessness signal success or failure for Vietnam's agrarian transition? Journal of Development Economics, 87(2), 191-209.

Reardon, T., Barrett, C. B., Berdegue, J. A., \& Swinnen, J. (2009). Agrifood industry transformation and farmers in developing countries. World Development, 37(11), 1717-1727.

Sadoulet, E., De Janvry, A., \& Fukui, S. (1997). The meaning of kinship in sharecropping contracts. American Journal of Agricultural Economics, 79(2), 394-406.

Shiferaw, B., \& Holden, S. T. (1998). Resource degradation and adoption of land conservation technologies in the Ethiopian highlands: A case study in Andit Tid, North Shewa. Agricultural Economics, 18(3), 233-247.

Simtowe, F., Mendola, M., Mangisoni, J., Tchale, H., \& Nyirongo, C. (2013). The economic effects of land redistribution: The case of a community-based rural land development project in Malawi. In S. T. Holden, K. Otsuka, \& K. Deininger (Eds.), Land tenure reform in Asia and Africa: Assessing impacts on poverty and natural resource management (pp. 105-133). London: Palgrave Macmillan.

Singh, I., Squire, L., \& Strauss, J. (1986). Agricultural household models: Extensions, applications, and policy. Washington, DC: The World Bank.

Sitko, N. J., \& Jayne, T. S. (2014). Structural transformation or elite land capture? The growth of "emergent" farmers in Zambia. Food Policy, 48, 194-202.

United Nations. (2014). World urbanization prospects: The 2013 revision. New York: United Nations Department of Economic and Social Affairs. 
Stein T. Holden is a professor in development and resource economics in the School of Economics and Business at the Norwegian University of Life Sciences, Ås, Norway. He is also an active member of the University's Centre for Land Tenure Studies, which was established in 2011 as a collaboration between four departments. He obtained his Ph.D. from the same university in 1991. He has worked there since 1992 as an associate professor and as a full professor since 2002. $\mathrm{He}$ has published a large number of scientific papers on issues related to land degradation and conservation, household economics and food security, land tenure and land markets, agricultural technologies and farming systems, bio-economic modelling and impact assessment.

Open Access This chapter is licensed under the terms of the Creative Commons Attribution 4.0 International License (http://creativecommons.org/licenses/by/4.0/), which permits use, sharing, adaptation, distribution and reproduction in any medium or format, as long as you give appropriate credit to the original author(s) and the source, provide a link to the Creative Commons license and indicate if changes were made.

The images or other third party material in this chapter are included in the chapter's Creative Commons license, unless indicated otherwise in a credit line to the material. If material is not included in the chapter's Creative Commons license and your intended use is not permitted by statutory regulation or exceeds the permitted use, you will need to obtain permission directly from the copyright holder. 